\title{
MENGUAK EKSISTENSI AKAL DAN WAHYU DALAM HUKUM ISLAM
}

\author{
Subehan Khalik \\ Fakultas Syariah dan Hukum Universitas Islam Negeri (UIN) Alauddin Makassar
}

\begin{abstract}
:
The Qur'an has hinted that its existence as a source of doctrine and law in Islam is very dominant. The picture can not only be observed in the Qur'anic statement of itself in various verses besides the establishment of Muslim jurists who place the Qur'an as the primary source. Regardless of the Qur'anic account of its existence in the law, in the view of Islamic theologians, the human mind is deemed capable of knowing God and thanking Him, knowing good and evil and including knowing his laws, even though revelation has not yet reached the servantExistence of the rational school of Islamic law has given birth new problems in legal discourse. The striking difference occurs in how far the tolerance of reason confronts the existence of revelation in elaborating Islamic law. Another problem arises as to how powerful revelation negates the function of reason (ratio) in the application of law.
\end{abstract}

Keywords:

Reason, Revelation, Islamic Law

\begin{abstract}
Abstrak:
Alquran telah mengisyaratkan bahwa eksistensinya sebagai sebagai sumber ajaran dan hukum dalam Islam sangat dominan. Gambaran itu tidak hanya dapat dicermati pada pernyataan Alquran tentang dirinya sendiri dalam berbagai ayat disamping penetapan para ahli hukum Islam yang menempatkan Alquran sebagai sumber utama. Terlepas dari uraian Alquran tentang eksistensinya dalam hukum, dalam pandangan para teolog Islam, akal manusia dipandang cakap untuk mengetahui Tuhan dan berterimakasih kepada-Nya, mengetahui baik dan buruk dan termasuk mengetahui hukumnya, meski wahyu belum sampai kepada hambaEksistensi mazhab rasional dalam hukum Islam telah melahirkan problematika baru dalam diskursus hukum. Perbedaan mencolok terjadi pada seberapa jauh toleransi akal menghadapi eksistensi wahyu dalam mengelaborasi hukum Islam. Timbul pula masalah lain yaitu seberapa kuat wahyu meniadakan fungsi akal (rasio) dalam penerapan hukum.
\end{abstract}

Kata Kunci:

Akal, Wahyu, Hukum Islam 


\section{A. PENDAHULUAN}

\section{Latar Belakang Masalah}

llah telah menurunkan syari'at terakhir yang diturunkn kepada Nabi
Muhammad saw. Syari'at ini memiliki ciri khas rasional dibekali wahyu
sebagai sumber rujukan guna menjadikan agama ini sebagai jalan yang lurus mencapai kebenaran di sisi Allah. Rasionalitas Islam sangat kontras pada eksistensi Alquran sebagai kitab suci yang sarat dengan tantangan dan corak pengetahuan. Beberapa pakar dalam ilmu pengetahuan telah mengalami persentuhan rasionalitas dengan Alquran dan pada akhirnya mereka menyatakan keimanan mereka terhadap Alquran.

Pada tataran berikutnya, hukum Islam kemudian menjadi sangat rasional karena Alquran sangat sarat dengan pesan penghormatan terhadap akal. Membuktikan eksistensi rasionalitas Islam dalam hukum dapat diperhatikan pada sumber alasan hukum yang dikenal dengan dalil. Semua Imam mazhab dalam upaya ijtihad mereka senantiasa menempatkan Alquran dan al-Sunnah sebagai sumber utama dan menjadikan dalil ijtihadi (dalil rasional) pada urutan selanjutnya. Diantara empat aliran mazhab dalam Islam, salah satu diantaranya memiliki kecenderungan menggunakan dalil rasional dibandingkan hadis ahad. Mazhab ini kemudian dikenal sebagai mazhab yang sangat rasional dibandingkan dengan tiga mazhab lainnya.

Eksistensi mazhab rasional dalam hukum Islam telah melahirkan problematika baru dalam diskursus hukum. Perbedaan mencolok terjadi pada seberapa jauh toleransi akal menghadapi eksistensi wahyu dalam mengelaborasi hukum Islam. Timbul pula masalah lain yaitu seberapa kuat wahyu meniadakan fungsi akal (rasio) dalam penerapan hukum.

\section{Permasalahan}

Tulisan ini akan membahas secara konfrehensif; Bagaimana eksistensi akal dan wahyu dalam hukum Islam dengan sub masalah sebagai berikut:

1. Bagaimana dominasi wahyu terhadap akal dalam hukum Islam

2. Bagaimana toleransi akal terhadap wahyu dalam hukum Islam

3. Bagaimana bentuk moderasi wahyu terhadap akal dalam hukum Islam

\section{B. PEMBAHASAN}

\section{Pengertian akal dan wahyu}

Akal secara bahasa berasal dari kata 'ain-qāf dan lām, menunjuk pada makna "tulang-tulangnya terkunci pada sesuatu, atau bermakna terkunci" dan karena itu, عقل dapat bermakna "mengunci secara kuat dalam perkataan dan perbuatan". ${ }^{1}$ Dari penjelasan ini dipahami bahwa akal bermakna sesuatu yang tersimpan dalam dan

\footnotetext{
${ }^{1}$ Abī al-Husain Aḥmad bin Fāris bin Zakariyā, Mu'jam Maqāyis al-Lugah, Juz IV, (Beirūt: Dār al-Fikr, t.th), h. 69 .
} 
terkunci pada lubuk hati sehingga pengetahuan tersebut secara spontan biasa terlontar dalam bentuk perkataan atau perbuatan. Seorang yang memiliki akal akan dengan mudah memanifestasikan pengetahuan mereka dalam bentuk perkataan ataupun perbuatan.

Kata ini dalam berbagai macam derivasinya digunakan dalam Alquran sebagai penghargaan bagi kalangan yang menggunakan pemikiran mereka yang bersumber dari akal. Tidak sedikit ayat Alquran yang menganjurkan dan mendorong manusia untuk menggunakan akal fikiran mereka. Kata yang sering digunakan dalam Alquran untuk menggambarkan proses berfikir itu misalnya dalam term 'aqala, ya'qilūna dan $t a^{\prime}$ qilūn. ${ }^{2}$

Secara berurut Alquran menggunakan kata 'aql sebanyak 49 kali dengan objek yang bermacam-macam. Diantara objek dimaksud meliputi; pemikiran terhadap dalil-dalil dan dasar keimanan, alam semesta, peringatan, sejarah keberadaan manusia, hukum, ibadah dan moral. Ayat dimaksud misalnya terdapat dalam QS. Al-Qașaș (28): 60

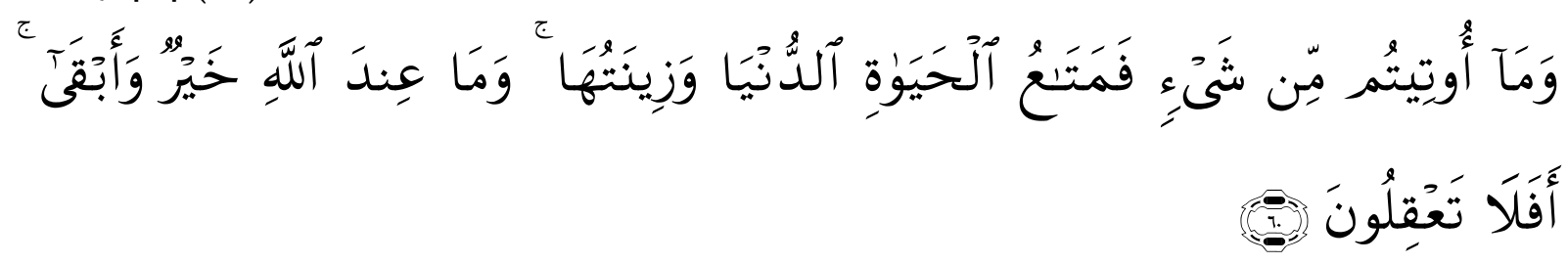

Terjemahnya :

Dan apa saja yang diberikan kepada kamu, Maka itu adalah ke-nikmatan hidup duniawi dan perhiasannya; sedang apa yang di sisi Allah adalah lebih baik dan lebih kekal. Maka Apakah kamu tidak memahaminya?.3

Wahyu berasal dari huruf waw-ḥa dan yā (وحي) bermakna "pemindahan pengetahuan dalam keadaan tersembunyi kepada orang lain". Dalam hal ini wahyu bermakna; "isyarat" dari Alquran dan al-Sunnah. Atau setiap apa yang disampaikan kepada orang lain hingga dia mengetahuinya, maka itu termasuk dalam kategori "wahyu". ${ }^{4}$ Dalam kata wahyu terdapat makna penyampaian sabda Tuhan kepada orang pilihan-Nya agar diteruskan kepada umat manusia dalam perjalanan hidupnya baik di dunia ini maupun di akhirat. Dalam Islam wahyu disampaikan kepada nabi Muhammad saw terkumpul semuanya dalam Alquran. ${ }^{5}$ Dari sisi peruntukannya, wahyu terbagi dalam tiga macam; wahyu yang ditujukan kepada orang khawas dan 'awam; wahyu yang hanya ditujukan kepada orang khawas saja dan wahyu yang ditujukan kepada orang awam saja. ${ }^{6}$

\footnotetext{
${ }^{2}$ Harun Nasutin, Akal dan Wahyu (Jakarta: UI Press, 1986), h. 52.

${ }^{3}$ Kementrian Agama RI. Alquran dan Terjemahnya (Jakarta: DKU Pint, 2015), h. 393.

${ }^{4}$ Abī al-Ḥusain Aḥmad bin Fāris bin Zakariyā, Mu'jam Maqāyis al-Lugah Juz VI, h. 94.

${ }^{5}$ Harun Nasutin, Akal dan Wahyu, h. 15.

${ }^{6}$ Muhammad Abduh, Risalah Tauhid, terjemahan M. Ali Akbar (Jogjakarta: Totah Surga, 1987), h. 60.
} 
Setelah mencermati dua pengertian tentang akal dan wahyu, maka didapatkan persamaan makna antara akal dan wahyu pada proses diterimanya informasi oleh akal manusia. Wahyu meskipun bersumber dari Tuhan, namun disampaikan dengan bahasa sederhana dan mudah untuk difahami oleh akal manusia. Dan akibat dari pemahaman tersebut melahirkan rentetan pengetahuan, meskipun pada akhirnya komunikan dalam proses penyampaian wahyu ini berbeda dalam tingkat kemampuan berfikir mereka.

\section{Dominasi Wahyu atas Akal}

Alquran telah mengisyaratkan bahwa eksistensinya sebagai sebagai sumber ajaran dan hukum dalam Islam sangat dominan. Gambaran itu tidak hanya dapat dicermati pada pernyataan Alquran tentang dirinya sendiri dalam berbagai ayat disamping penetapan para ahli hukum Islam yang menempatkan Alquran sebagai sumber utama.

Terlepas dari uraian Alquran tentang eksistensinya dalam hukum, dalam pandangan para teolog Islam, akal manusia dipandang cakap untuk mengetahui Tuhan dan berterimakasih kepada-Nya, mengetahui baik dan buruk dan termasuk mengetahui hukumnya, meski wahyu belum sampai kepada hamba. Pendapat ini dikemukakan oleh kelompok Mu'tazilah yang disokongi oleh Abū al-Huzail. ${ }^{7}$ Lebih jauh lagi, al-Murdar bahkan mengemukakan bahwa kewajiban mengetahui Tuhan, berterimakasih kepada Tuhan, termasuk di dalamnya mengetahui hukum-hukum berikut sifat-sifat Tuhan adalah wajib meskipun wahyu belum sampai kepada hamba. Jika hamba ini tidak melakukan yang demikian, maka ia akan kekal di dalam neraka. ${ }^{8}$

Kelompok yang kemudian mengambil jarak dan berbeda dengan alur fikir di atas adalah kelompok al-Asy'ari. Kelompok ini menegaskan bahwa hanya wahyu lah yang dapat mengetahui Tuhan, berterima kasih kepada-Nya dan mengetahui suatu perbuatan itu baik atau jahat. ${ }^{9}$ Wahyu pula yang kemudian mewajibkan mengetahui Tuhan dan berterima kasih kepada-Nya, juga dengan wahyu pula diketahui kepatuhan kepada Tuhan akan mendapatkan upah dan ketidakpatuhan akan mendapatkan ganjaran. ${ }^{10}$

Alas teologi al-Asy'ari kemudian melahirkan anggapan umum di kalangan umat Islam bahwa wahyu dalam hukum memiliki otoritas yang sangat tinggi dibanding akal manusia. Sedemikian tingginya eksistensi wahyu tersebut menyebabkan akal hanya berfungsi sebagai konfirmator semata. Argumentasi kalangan Asy'ari sangat beralasan jika dihubungkan dengan kedudukan wahyu

\footnotetext{
${ }^{7}$ Harun Nasution, Teologi Islam, Alira-Aliran, Sejarah, Analisa Perbandingan (Jakarta: UI Press, 2009), h. 82 .

${ }^{8}$ Harun Nasution, Teologi Islam, h. 83.

${ }^{9}$ Harun Nasution, Teologi Islam, h. 84-85.

${ }^{10}$ Harun Nasution, Teologi Islam, h. 85.
} 
sebagai sumber hukum utama. ${ }^{11}$ Inilah yang melandasi kuatnya penempatan wahyu sebagai sumber utama dalam hukum Islam sehingga pada tahapan selanjutnya, eksistensi akal manusia seolah-olah hanya sebagai alat pemaham dari untaian maksud dan tujuan wahyu.

Menempatkan wahyu dalam posisi superior dibanding akal adalah argumentasi yang cukup beralasan mengingat keterbatasan akal manusia pada sisi lain yang harus bersentuhan dengan alam empirik untuk mengetahui objek dan tujuan sesuatu. Dalam struktur imam mazhab, tiga dari empat mazhab menempat kan wahyu pada posisi dominan dibanding akal. Logika penetapan dibangun atas premis bahwa Tuhan menurunkan wahyu kepada manusia sebagai alat informasi tentang berbagai hal termasuk di dalamnya hukum yang akan mereka tegakkan. Argumentasi tersebut biasa dianalisa dari beberapa fakta bahwa dalam Alquran terdapat ayat-ayat yang tidak secara terbuka dapat difahami oleh akal manusia tanpa wahyu. Masa Rasulullah saw tak dapat dipungkiri sebagai masa dominasi wahyu terhadap akal. Pada masa ini, Rasulullah saw. sebagai pembuat hukum sesudah Allah dapat secara leluasa menentukan formasi hukum yang bersumber dari wahyu tanpa harus mengupayakan fungsi akal secara maksimum untuk memahami khițāb al-hukm dari wahyu.

Beberapa contoh dominasi wahyu terhadap akal dapat dilihat dari beberapa kasus sebagai berikut:

Kasus Ban̄i Qurayẓah; Saat itu Rasulullah saw memerintahkan sahabat agar melaksanakan shalat Ashar setiba mereka di perkampungan Ban̄̄ Qurayẓah. Sebagian sahabat kemudian melaksanakan shalat Ashar sebelum mereka tiba di tempat tersebut, dan sebagian lagi melaksanakan shalat Ashar setiba di perkampungan Ban̄i Qurayzah. Oleh Rasulullah, perbuatan sahabat yang melaksanakan shalat Ashar sebelum tiba di perkampungan Banī Qurayzah bukanlah merupakan masalah sebab merek mempertimbangakan aspek waktu Ashar yang akan keburu habis, sementara sebagian sahabat yang melaksanakan shalat Ashar di perkampungan Ban̄̄ Qurayẓah juga tidak mendapatkan teguran meski secara faktual mereka shalat setelah waktu Ashar telah habis. ${ }^{12}$

Dalam kasus jilatan anjing terhadap bejana, sangat kontras dominasi wahyu atas akal mengingat peristiwa tersebut mengahruskan seseorang untuk mencuci bekas jilatan anjing pada bejana dengan 7 kali cucian. Salah satu diantaranya dengan menggosok tanah pada jilatan tersebut. Pertanyaan yang mengemuka adalah; Bagaimana eksistensi tanah sebagai pembersih jilatan anjing padahal sudah diketahui bersama bahwa alasan seseorang untuk bersuci atau mandi adalah karena mereka telah terjiprat oleh kotoran atau tanah. Pada posisi ini, tanah diidentikkan dengan kotoran dan kotoran dalam hukum Islam tak dapat dijadikan sebagai alat

${ }^{11}$ Harun Nasution, Teologi Islam, h. 86.

12 'Abd al-Hamīd al-Mutawalli, Mabādi' Niz̄ām al-Hukm Fi al-Islām (Iskandariyah: Mansya'ah alMa’rifah, 1998), h. 51. 
bersuci. Pertanyaan yang mengemuka adalah mengapa dalam kasus ini kotoran (tanah) menjadi alat yag penting dalam membersihkan jilatan anjing pada bejana. Sampai saat ini jilatan anjing pada bejana tidak dapat dihilangkan secara sempurna tanpa menggosokkan tanah pada permukaan bejana yang telah dijilat. Penggunaan deterjen ternyata tidak mampu menghilangkan bekas jilatan dan tanahlah yang terbukti secara empiric mampu menghilangkan bekas jilatan anjing tersebut.

Hukum Islam telah mengharamkan daging babi untuk kaum muslimin, begitupula dengan darah dan bangkai. Pada kasus ini, akal secara sempurna akan mengetahui jika darah dan bangkai adalah sesuatu yang kurang baik. Sementara cakupan hukum pada ayat ini menjelaskan posisi bangkai dan darah setara dengan daging babi. Daging babi tidak dapat diketahui oleh akal manusia dan jika wahyu tidak memberi informasi bahwa daging babi adlah seuatu yang diharamkan, maka akal pun juga tidak mampu menyatakan bahwa daging babi ini juga haram.

Alquran telah menunjukkan manusia keburukan dari perbuatan zina, semantara akal tak dapat memahami petunjuk ini tanpa adanya justifikasi wahyu. Wahyu memberi pengetahuan yang sempurna bahwa perbuatan zina itu berakibat pada rusaknya struktur keturunan manusia serta pelakunya diancam untuk diganjar dengan hukuman. Dominasi wahyu pada sampel ini sangat jelas mengingat akal tidak akan mampu memberi justifikasi bahwa perbuatan zina itu adalah sesuatu yang buruk.

Beberapa riwayat yang berkaitan dengan ibadah juga menunjukkan dominasi wahyu terhadap akal. Gerakan-gerakan shalat secara murni merupakan dominasi wahyu dan porsi akal untuk memikirkannya sangat kecil. Rasulullah saw ketika berbicara tentang cara shalat witir senantiasa menghimbau kaum muslimin untuk tidak mempertanyakan panjang dan durasi shalat witir yang dilkukan olehnya. Pada tataran lain terdapat hal lain yang sangat sulit untuk didekati dengan pendekatan akal semisal buang angin yang dapat membatalkan wudhu seseorang. Akal tidak akan mampu mencerna mengapa ketika seseorang buang angin dalam keadaan berwudu akan batal sebab perbuatan tadi. Jika menggunakan akal sebagai pendekatan, maka orang yang buang angin seharusnya diperintahkan untuk cebok.

\section{Dominasi Akal atas Wahyu}

Dalam bagian ini akan dibahas peran akal terhadap eksistensi wahyu yang kadang dianggap pakem. Pemahaman yang kaku terhadap wahyu seolah menutup peluang bagi akal untuk mengelaborasinya sehingga muncul kelompok yang secara kaku pula memahami wahyu apa adanya. ${ }^{13}$ Berbeda dengan kelompok tadi, 'Umar bin Khațāāb telah menjadi pelopor utama esksistensi akal terhadap wahyu. Dia telah meletakkan akal tampak seolah menjadi dominan atas wahyu. Dominasi akal terhadap wahyu dapat dilihat pada hadis berikut:

${ }^{13}$ Contoh yang paling jelas dapat diperhatikan pada metoda istimbāt kaum penganut mazhab z̧ahiriyyah yang sangat pakem terhadap makna tersurat dari sebuah naṣ. 


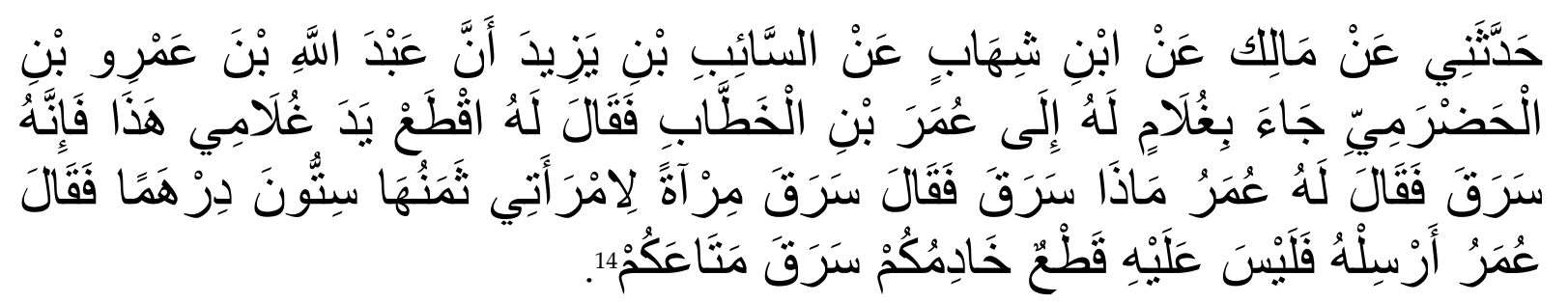

Artinya:

Telah menceritakan kepadaku dari Mālik dari Ibnu Syihāb dari As Sā’ib bin Yāzid bahwa 'Abdullāh bin Amru bin Al Hadrami datang dengan pembantunya kepada Umar bin Khațtāb, seraya berkata; "Potonglah tangan pembantuku ini, dia telah mencuri! "Umar bertanya; "Apa yang dia curi?" dia menjawab; "Dia mencuri cermin isteriku yang harganya enam puluh dirham." Umar berkata; "Bebaskan dia, karena tidak ada potong tangan untuk pembantumu yang mencuri hartamu."

Secara nyata kasus ini meniadakan hukuman potong tangan terhadap budak pelaku pencurian. Dalam pandangan Imam Malik dan Imam Syafi' dispensasi 'Umar terhadap pelaku adalah sebuah takhșiṣ atas ayat Alquran yang masih berstatus muțlaq. ${ }^{15}$ Pada tataran inilah secara nyata muncul ke permukaan dominasi akal atas wahyu, sebab factor utama dalam hukum pidana pencurian yaitu potong tangan mengalami perubahan arah dengan mengganti hukuman atas pelaku dengan $t a^{\prime} \dot{z} \bar{\imath} r$.

Sahabat-sahabat telah diperkenalkan dengan metode berijtihad sejak masa Rasul. Tercatat dalam sejarah bahwa 'Amr ibn al-Aș adalah seorang sahabat yang pernah mendapatkan kepercayaan selaku hakim. Dalam kondisi ini 'Amr ibn al-Aș kemudian bertanya lansung kepada Rasulullah saw. perihal kebolehannya untuk menyelesaikan permasalahan hukum kaum muslimin. Pada saat itu Rasulullah saw. hanya menjawab bahwa jika ia ('Amr ibn al-Aș) berijtihad dan ijtihadnya benar, maka baginya dua pahala dan jika sebaliknya, maka baginya hanya satu pahala. ${ }^{16}$ Lebih lengkapnya, hadis tentang ijtihad hakim yang digambarkan di atas adalah sebagai berikut :

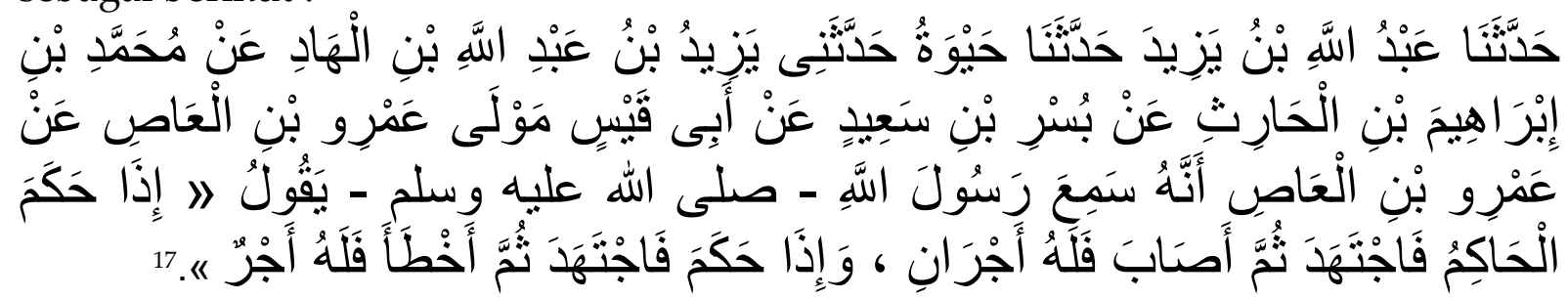

Artinya:

Telah diberitakan 'Abdullāh bin Yazìd kepada kami, telah diberitakan Haywah, telah diberitakan kepadaku Yazīd bin 'Abdullāh bin al-Hādi dari Muhammad bin Ibrāhim bin al-

\footnotetext{
${ }^{14}$ Mālik bin Ānas bin Mālik bin Ab̄̄ Āmir, Muwațta Mālik, Juz V, (Beirut: Dār al-Fikr, t.th.), h. 1229.

${ }^{15}$ A. Hanafi, Ushul al-Fiqh (Jakarta: Widjaya, 1963), h. 75.

16 Amiur Nuruddin, Ijtihad 'Umar Ibn Khaththab: Studi Tentang Perubahan Hukum Dalam Islam (Jakarta: Rajawali Press, 1987), h. 54.

${ }^{17}$ Abū 'Abdullāh Muḥammad bin Ismā’̄il bin Ibrāḥim Ibn al-Mugīrah bin Bardizbat al-Bukhārīy, Șaḥịh al-Bukhārīy, juz XXIV, (t.t. Dār Maṭba’ah al-Syabi, t.th), h. 166.
} 
Hāris̉ dari Busri bin Sa'îd dari Ab̄̄ Qays budak dari "Amr bin Aṣ, sesungguhnya dia mendengar rasulullah saw. berkata: "Jika seorang hakim melakukan penegakan hukum kemudian dia melakukan ijtihad kemudian ijtihdnya benar, maka baginya dua pahala dan jika dia berijtihad kemudian dia salah, maka baginya hanya satu pahala.

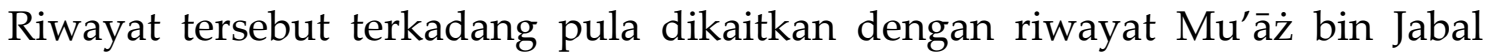
ketika akan diutus ke Negeri Yaman untuk menjadi hakim. Namun sebagian menolak dengan alasan bahwa riwayat tentang $\mathrm{Mu}^{\prime} \mathbf{a} \dot{z}$ tersebut adalah hadis mursal. Meski demikian, riwayat ini memberi andil terhadap pemanfaatan akal untuk mengelaborasi hukum.

Pemanfaatan akal dalam masa Rasul telah memberi jalan terhadap dominasi akal, namun perlu diberi penekanan bahwa dominasi akal tidak dalam arti meniadakan fungsi wahyu, akan tetapi menjadi alat utama untuk memahami wahyu itu sendiri. Setidaknya, inilah yang menjadi landasan para ahli ușūl al-figh untuk menyatakan bahwa domain ijtihad sebagai turunan dari akal hanya dapat berlaku pada persoalan yang tidak diatur secara jelas dalam Wahyu (Alquran dan alSunnah). Landasan ini terlihat pada pola ijtihad dari zaman ke zaman yang tidak memasuki lahan yang telah diatur secara jelas oleh Wahyu.

Dominasi akal atas wahyu pasca wafatnya Rasulullah saw menjadi sangat kontras ketika wilayah kekuasaan kaum Muslimin menjadi sangat luas dan multi etnik. Pada masa kekuasaan 'Umar bin Khațāb, terjadi berbagai macam persoalan hukum yang harus diselesaikan ketika itu. Maka tak heran jika berbagai fakta kemudian muncul dan diduga penyelesaian 'Umar bin Khațāa terhadap masalah tersebut adalah pola dominasi akal terhadap wahyu.

Diantara contoh klasik perlawanan itihad 'Umar bin Khațāab terhadap wahyu adalah ketika ia bersikap untuk menutup peluang orang-orang yang baru memeluk Islam (mu'allaf) menerima bagian dari zakat yang dikeluarkan oleh kaum Muslimin. 'Umar bin Khaț̣āb berprinsip bahwa penolakan tersebut sangat berdasar mengingat kondisi umat Islam tidak lagi lemah dan butuh penganut, melainkan Islam kala itu telah menjadi sebuah Negara Adidaya dengan jumlah penganut yang sangat banyak. Dominasi akal oleh 'Umar bin Khațtāb telah melawan ketentuan kelompok delapan sebagaimana dalam QS. Al-Taubah (09): 59:

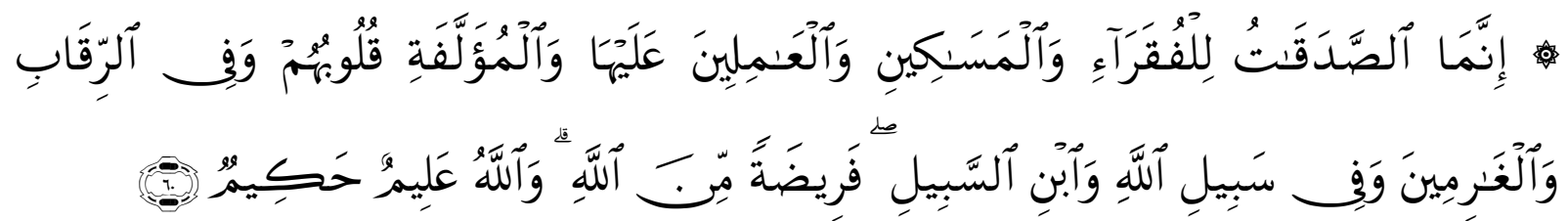

Terjemahnya :

Sesungguhnya zakat-zakat itu, hanyalah untuk orang-orang fakir, orang-orang miskin, pengurus-pengurus zakat, Para mu'allaf yang dibujuk hatinya, untuk (memerdekakan) budak, orang-orang yang berhutang, untuk jalan Allah dan untuk mereka yuang sedang 
dalam perjalanan, sebagai suatu ketetapan yang diwajibkan Allah, dan Allah Maha mengetahui lagi Maha Bijaksana. ${ }^{18}$

Ayat ini secara jelas memberi hak kepada kelompok keempat dari delapan kelompok yang disebutkan berhak atas zakat. Sekaligus menjadi landasan kuat untuk menyatakan bahwa wahyu pada saat 'Umar bin Khațāāb menetapkan kebalikan dari perintah pada ayat ini, telah diposisikan pada kondisi terdominasi oleh akal (ijtihad).

\section{Moderasi Akal terhadap Wahyu}

Moderasi akal terhadap wahyu merupakan upaya berkelanjutan akal manusia mendalami sebuah perintah Tuhan. Dalam konteks ini, sebuah perintah sangat sulit untuk dijelaskan oleh akal fikiran manusia karena keterbatasan pengetahuan. Contoh yang paling dekat dengan pengelompokan ini adalah isyarat akal terhadap atmosfir bumi sebagaimana dalam QS. Al-An'ām (06): 125:

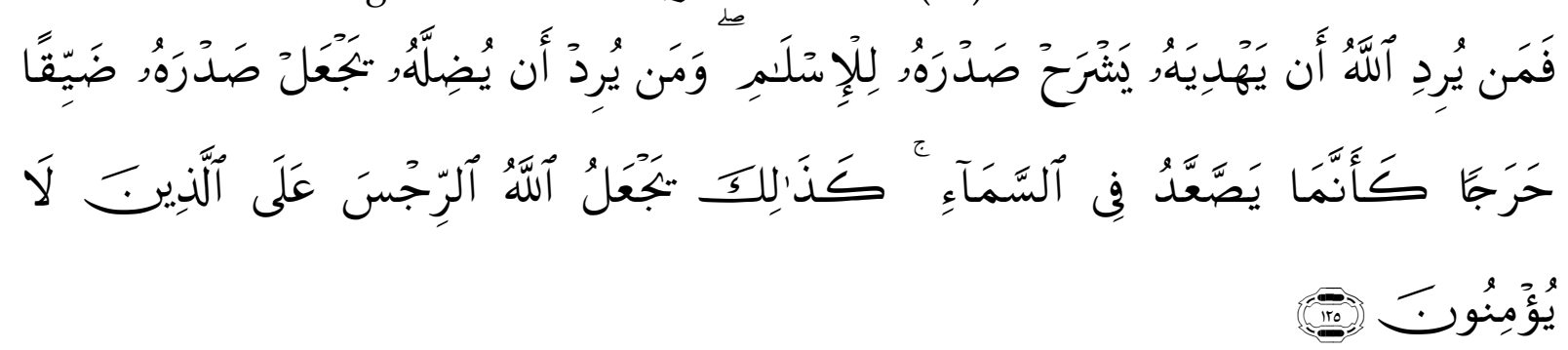

Terjemahnya:

Barangsiapa yang Allah menghendaki akan memberikan kepadanya petunjuk, niscaya Dia melapangkan dadanya untuk (memeluk agama) Islam. dan Barangsiapa yang dikehendaki Allah kesesatannya, niscaya Allah menjadikan dadanya sesak lagi sempit, seolah-olah ia sedang mendaki langit. Begitulah Allah menimpakan siksa kepada orang-orang yang tidak beriman. ${ }^{19}$

Atmosfir bumi di angkasa luar memerlukan waktu yang panjang untuk dimengerti sebagaimana tercantum dalam ayat ini. Akal pada masa awal Islam sangat sulit untuk memberi interpretasi maupun pengertian terhadap ayat ini mengingat perkembangan ilmu antariksa saat itu masih sangat sederhana. Sebaliknya masa moderen saat ini, kajian mendalam terhadap ilmu antariksa telah menemukan bahwa permukaan udara ketika mencapai ketinggian tertentu pada lapisan udara luar bumi akan semakin berkurang, bahkan semakin habis. Memaknai kata dada sesak pada ayat di atas menjadi sangat ilmiyah dan masuk akal ketika ilmu antariksa telah mencapai pengetahuan terhadap lapisan udara permukaan.

Moderasi akal atas wahyu memiliki kemiripan dengan pemikiran Fazlur Rahman tentang gerak ganda (double movement). Dalam teori ini, Fazlur Rahman

\footnotetext{
${ }^{18}$ Kementrian Agama RI. Alquran dan Terjemanya, h. 196

${ }^{19}$ Kementrian Agama, Alquran dan Terjemahnya, h. 144.
} 
mensinyalir dua gerakan yang saling berpengaruh dan saling melengkapi. Gerak pertama berisi pemahaman dasar yang masih asli pada masa kenabian terhadap Firman Allah di tengah-tengah kondisi sosio-kultural kaum muslimin saat itu. Sementara gerak kedua adalah adalah upaya terstruktur pembaca Firman Allah pada masa kontemporer yang akan menghasilkan pemahaman dan rumusan yang berselaras dengan Firman Allah pada masa awal. ${ }^{20}$

Hukum Kewarisan dalam Islam turut memberi sumbangan yang cukup besar dalam konteks moderasi akal terhadap wahyu. Kasus-kasus kewarisan yang dikemukakan dalam Alquran masih sangat umum dan tidak mampu menggapai rasa keadilan terhadap para penggunanya. Sementara di lapangan, terjadi variasi kasus akibat beragamnya masyarakat muslim dn semakin luasnya cakupan wilayah kekuasaan Islam. Kasus klasik yang menjadi contoh dalam kewarisan Islam adalah kasus 'Umariyatain (Kasus yang diselesaikan secara adil oleh 'Umar bin Khaț̣āb lewat upaya moderasi akal dalam soal kewarisan kakek dan nenek).

Moderasi akal terhadap wahyu juga memiliki kesesuain dengan teori "konflik dan ketegangan" dalam hukum Islam milik Noel J. Coulson. Lebih jauh, Noel J. Coulson menggunakan pendekatan filsafat antinomi guna mendekati hukum Islam dalam pertentangan akal dan wahyu. ${ }^{21}$ Teori ini berbeda dengan pemikiran kebanyakan dari orientalis yang mendahulukan konflik dibanding penyelesaian masalah akal dan wahyu pada sebuah perselarasan. Moderasai akal terhadap wahyu membuka peluang pada peningkatan kemampuan akal dalam mengelolah perintah Tuhan. Akal manusia yang bersumber dari Tuhan harus ditempatkan pada posisi sebagai penunjang manusia dalam memahami dan menganalisa macam perintah Tuhan yang masih bersifat umum dalam wahyu.

Moderasi akal terhadap wahyu diberi posisi penting dalam filsafat hukum Islam dengan menempatkan kesempurnaan akal untuk menilai perbuatan hukum mukallaf. Seorang yang memiliki akal yang sempurna digambarkan sebagai person yang mumayyiz dan memiliki kewajiban syara' dalam memikul beban hukum. Kesempurnaan akal juga menjadi titik tumpu paling utama untuk menilai perbuatan hukum mukallaf ketika berbuat sebuah perbuatan hukum. Jika digambarkan secara ringkas, kesempurnaan akal menjadi landasan utama menilai perbuatan mukallaf dalam dua tingkat. Tingkat pertama adalah kesempurnaan akal manusia pada saat mukallaf berangsur menjadi dewasa dan tingkat kedua adalah ketika mukallaf tersebut melakukan perbuatan hukumnya. Orang gila dalam konteks ini akan terlepas dari tuntutan apapun terhadap syara' begitupula dengan anak kecil serta orang yang sedang tidur sampai ia terbangun.

${ }^{20}$ Nurcholish Madjid, "Fazlur Rahman dan Rekonstruksi Etika al-Qur'an dalam Islamika, No. 2 OktoberDesember, 1993, h. 28.

21 Purnadi Purbacaraka dan Soejono Soekanto, Ikhtisar Antinomi; Aliran Filsafat Sebagai Landasan Filsafat Hukum (Jakarta: Rajawali Press, 1991), h. 22. 
Moderasi akal terhadap wahyu dalam kesempurnaan akal manusia guna memikul beban (takîf) dikemukakan oleh wahyu sebagaimana hadis Nabi saw sebagaimana berikut:

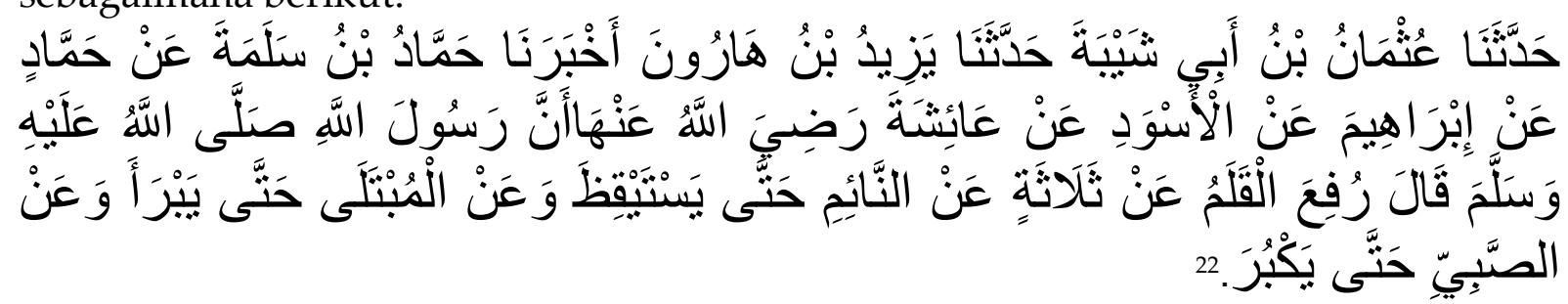

Artinya:

Telah menceritakan kepada kami Uśmān bin Abū Syaibah berkata, telah menceritakan kepada kami Yazìd bin Hārun berkata, telah mengabarkan kepada kami Hammād bin Salamah dari Hammād dari Ibrāhim dari Al-Aswad dari 'Āisyah Radiallāhu 'anhā bahwa Rasulullah sallallahu 'alaihi wasallam bersabda: "Pena pencatat amal dan dosa itu diangkat dari tiga golongan; orang yang tidur hingga terbangun, orang gila hingga ia waras, dan anak kecil hingga ia balig."

Hadis Nabi di atas adalah penggambaran kesempurnaan akal mukallaf dalam hukum. Proses penyempurnaan akal haruslah melewati jalur pertama yakni sejak bayi kemudian beranjak menjadi dewasa yang biasanya ditandai dengan matangnya fungsi seksual. Kematangan inilah yang biasa dimaknai dengan kedewasaan dalam pandangan hukum (mukallaf). Meski belum diadakan penelitian khusus seputar keterhubungan kedewasaan dengan kesempurnaan akal, namun indikasi jika kedewasaan mengarahkan seseorang pada kesempurnaan akal dapat menjadi bahan kesimpulan bahwa telah terjadi kesempurnaan akal seiring dengan tingkat kedewasaan seseorang. Lantas bagaimana dengan mukallaf yang kemudian mengalami kedewasaan dalam fungsi-fungsi seksual namun tidak dalam kesempurnaan akalnya, apakah mereka akan dihukumi sama dengan mukallaf. Jawabannya adalah tidak, mengingat syarat kesempurnaan akal masih terikat dengan syarat kesempurnaan akal dengan tidak tergangunya akal seseorang karena kegilaan. Penjenjangan kesempurnaan akal dari kedewasaan fungsi seksual, ketiadaan gangguan terhadap akal (sakit ingatan), selanjutnya memasuki fase ketiga yaitu ketiadaan akal karena tidur (sesaat).

Penjenjangan proses kedewasaan yang seiring dengan perkembangan akal merupakan landasan hukum Islam menetapkan keberlakuan hukum pada mukallaf sekaligus menjadi dasar peniadaan hukum bagi mereka. Karena itu, hukum Islam lantas mencabut ketiadaan beban mukallaf dengan ketiadaan kesempurnaan pada akal seseorang. Rasulullah menyatakan bahwa; "Agama adalah akal, tiada agama bagi mereka yang tidak memiliki akal" merupakan landasan kuat untuk menyatakan

\footnotetext{
${ }^{22}$ Sunan Ibnu Mājah, Sunan Ibn Mājah, Juz IV (Beirūt Dār al-Fikr, t.th), h. 243.
} 
bahwa akal dan wahyu dalam agama Islam haruslah bersinergi dan tidak berseberangan dengan ketegangan ataupun konflik.

\section{KESIMPULAN}

Agama Islam telah menempatkan wahyu pada posisi yang lebih dominan terhadap akal pada hal-hal perintah pokok. Perintah ini biasanya dalam urusan ibadah serta beberapa kejadian yang berhubungan dengan perintah Rasulullah saw pada masanya.

Sisi lain dari agama Islam adalah terjadinya dominasi akal terhadap wahyu pada beberapa kasus yang mengharuskan mereka berijtihad pada kasus-kasus yang dianggap mapan. Contoh paling kontras dari dominasi ini dapat dilihat pada kesimpulan 'Umar bin Khațāa meniadakan hukuman potong tangan bagi pencuri pada kasus pencurian yang dilakukan oleh seorang hamba sahaya.

Moderasi akal terhadap wahyu dapat ditemukan pada proses penerimaan akal lewat kemampuan interaksi akal terhadap sains dan ilmu pengetahuan pada penjelasan wahyu semisal perjalanan panjang akal memahami ketiadaan udara pada ruang angkasa pada ketinggian atmosfir tertentu. Sebaliknya, wahyu menempatkan kesempurnaan akal terhadap pemberlakuan syariat kepada seorang mukallaf. Dalam konteks ini akal dan wahyu membangun sinergi yang sempurna dan terhindar dari saling menafikan. Inilah jawaban bagi orientalis yang lebih mengedepankan konflik akal dan wahyu dalam proses pemahaman hukum.

\section{Daftar Pustaka}

A. Hanafi, Ushul al-Figh (Jakarta: Widjaya, 1963)

Abduh, Muhammad, Risalah Tauhid, terjemahan M. Ali Akbar (Jogjakarta: Totah Surga, 1987)

Abī Āmir, Mālik bin Ānas bin Mālik bin, Muwațța Mālik, Juz V, (Beirut: Dār al-Fikr, t.th.)

Aḥmad bin Fāris bin Zakariyā, Abī al-Ḥusain, Mu'jam Maqāyis al-Lugah, Juz IV, (Beirūt: Dār al-Fikr, t.th)

al-Bukhārīy, Abū 'Abdullāh Muḥammad bin Ismā'îl bin Ibrāḥim Ibn al-Mugīrah bin Bardizbat, Șạ̄ị al-Bukhārīy, juz XXIV, (t.t. Dār Mațba'ah al-Syabi, t.th)

al-Mutawalli, 'Abd al-Ḥamīd, Mabādi' Niz̄ām al-Hukm Fi al-Islām (Iskandari yah: Mansya' ah al-Ma'rifah, 1998)

Ibnu Mājah, Sunan, Sunan Ibn Mājah, Juz IV (Beirūt Dār al-Fikr, t.th)

Kementrian Agama RI. Alquran dan Terjemahnya (Jakarta: DKU Print, 2015)

Nasution, Harun, Akal dan Wahyu (Jakarta: UI Press, 1986) 
Nasution, Harun, Teologi Islam, Alira-Aliran, Sejarah, Analisa Perbandingan (Jakarta: UI Press, 2009)

Nurcholish Madjid, “Fazlur Rahman dan Rekonstruksi Etika al-Qur'an dalam Islamika, No. 2 Oktober-Desember, 1993

Nuruddin, Amiur, Ijtihad 'Umar Ibn Khaththab: Studi Tentang Perubahan Hukum Dalam Islam (Jakarta: Rajawali Press, 1987)

Purbacaraka, Purnadi dan Soejono Soekanto, Ikhtisar Antinomi; Aliran Filsafat Sebagai Landasan Filsafat Hukum (Jakarta: Rajawali Press, 1991) 